\title{
Gene amplification and overexpression of HER2 in renal cell carcinoma
}

\author{
Z. LATIF, A.D. WATTERS, J.M.S. BARTLETT, M.A. UNDERWOOD and M. AITCHISON* \\ Department of Surgery, Glasgow Royal Infirmary, and *Department of Urology, Gartnavel General Hospital, Glasgow, UK
}

Objective To determine the frequency of HER2 genetic abnormalities in renal cell carcinoma (RCC) and hence assess the potential suitability of Herceptin ${ }^{\text {TM }}$ immunotherapy.

Patients and methods Tumours from 27 patients with RCC were assessed; all patients had undergone nephrectomy. Benign renal tissue from the nephrectomy specimens was studied in seven patients. Gene amplification was assessed using fluorescent in-situ hybridization, and protein over-expression using immunohistochemistry.

Results Twenty-four patients had clear cell renal carcinoma, two had papillary renal carcinoma and one a sarcomatoid variant carcinoma. There was no
HER2 amplification in the tumours or the benign renal tissue. Polysomy 17 was detected in 11 of 27 tumours $(41 \%)$ and increased HER2 copy number in seven $(26 \%)$. Both polysomy 17 and increased HER 2 copy number were absent in the benign renal tissue. Three tumours (11\%) and six of the seven benign renal tissue samples over-expressed the HER2 protein.

Conclusions HER2 amplification is absent and protein over-expression uncommon in RCC. This casts doubt on the suitability of Herceptin ${ }^{\mathrm{TM}}$ in the treatment of RCC.

Keywords renal carcinoma, HER2, Herceptin ${ }^{\mathrm{TM}}$, FISH, immunohistochemistry

\section{Introduction}

Patients with locally advanced or metastatic RCC have a poor prognosis; the 5-year survival for patients with stage IV disease is $10 \%$ [1], reflecting that RCC is largely resistant to conventional therapeutic regimens [2]. Immunotherapy using interleukin-2 and interferon- $\alpha$ combined has shown response rates of up to $18.6 \%$ in patients with metastatic disease, but is associated with significant side-effects [3]. Negrier et al. [3] reported grade 3 and 4 adverse events like hypotension (resistant to vasopressor agents) and fever in $45 \%$ and $35 \%$ of patients, respectively. A better understanding of the molecular genetics of RCC may help in the development of new therapeutic agents. Aneusomy of chromosome 17 has been reported in papillary RCC [4,5]. The HER 2/c-erbB2 gene is located on chromosome 17 and encodes a transmembrane type I tyrosine kinase growth factor receptor with $50 \%$ homology with the EGFR [6-8]. Over-expression of HER2 has been reported in breast [9-11], ovarian [9], lung [12] and salivary gland tumours [13], and is associated with a poorer prognosis. In a recent review examining the results of 47 studies involving > 22600 patients with breast cancer, HER2positive status was an independent predictor of poor prognosis in multivariate analysis [14]. Herceptin ${ }^{\mathrm{TM}}$

Accepted for publication 2 September 2001
(rhu-mAb-HER2, Trastuzumab, Genentech Inc., San Francisico, CA) is the humanized equivalent of the murine $4 \mathrm{D} 5 \mathrm{mAb}$ and is targeted against the HER2 cell-surface receptor. Phase II and phase III clinical trials in patients with breast cancer over-expressing the HER 2 oncogene showed response rates of $11-15 \%$ $[15,16]$. A recent study showed that $40 \%$ of RCCs over-express the HER2 protein and 17\% show gene amplification $[17,18]$. However, other studies have not confirmed these findings, suggesting that the HER2 expression and amplification rates are lower [19-21]. These differences may be partly explained by the different laboratory techniques used in the various studies. Determination of protein over-expression by immunohistochemistry (IHC) is highly dependent on the antibody selected and the methods used. Fluorescent in-situ hybridization (FISH) is the approved diagnostic method for determining gene amplification, allowing in-situ analysis of gene copy number. The Glasgow Royal Infirmary is one of three UK centres evaluating HER2 status in breast cancer diagnosis [22]. In the present study we evaluated the HER 2 status of 27 RCCs and seven benign renal tissues using FISH and IHC.

\section{Patients and methods}

Tumours from patients with a pathological diagnosis of RCC and attending the Gartnavel General Hospital 
between 1997 and 1999 were included in the study. All patients underwent nephrectomy and tumours were assigned TNM [23] and Robson stages [24] and grades [25]. Benign (normal) renal tissue was identified from the RCC nephrectomy specimens. IHC was performed using the CB11 mouse mAb and the Nexus II automated staining system (both from Ventana, UK). Formalin-fixed paraffin-embedded $5 \mu \mathrm{m}$ sections and positive/negative controls were used in each run. Antigens were retrieved in a pressure cooker for $12 \mathrm{~min}(1 \mathrm{~L}$ distilled water and $1.8 \mathrm{mmol}$ of EDTA at $\mathrm{pH} 8$ in an $850-\mathrm{W}$ microwave oven), followed by a 20-min cooling period. Endogenous biotin was blocked by applying avidin for $15 \mathrm{~min}$ and then biotin for $15 \mathrm{~min}$ (SP-2001, Vector Laboratories, Burlinghame, USA). The slides were transferred to the Nexus II and the basic diaminobenzidine detection kit (Ventana) applied; $100 \mu \mathrm{L}$ of $\mathrm{CB} 11$ was added manually to each slide as appropriate and incubated in the Nexus II for $32 \mathrm{~min}$. The result was scored by two independent observers. Routine sections stained with haematoxylin and eosin were examined to identify areas of tumour or benign renal tissue, and corresponding areas marked on the IHC sections. IHC was scored according to both the intensity and number of cells stained. No staining or membrane staining in $<10 \%$ of cells was scored as 0 ; weak staining of the membrane in $>10 \%$ of cells was scored as $1+$ moderate membrane staining in $>10 \%$ of cells was scored as $2+$, and strong membrane staining in $>10 \%$ of cells as $3+$. Cytoplasmic stained was excluded. A score of $2+$ or $3+$ was regarded as 'positive' and a score of 0 or $1+$ as 'negative' [26].

FISH was performed as previously described [27,28]; briefly, slides were pretreated with $0.2 \mathrm{~mol} / \mathrm{L} \mathrm{HCl}, 8 \%$ sodium thiosulphate at $80^{\circ} \mathrm{C}$ and $0.5 \%$ pepsin at $37^{\circ} \mathrm{C}$. Sections were post-fixed in $10 \%$ neutral buffered formalin. The extent of digestion was estimated by applying $0.5 \mu \mathrm{g} / \mathrm{mL}$ 4,6-diamidoino-2 phenylindole-2 hydrochloride in Vectashield (Vectorlabs, Peterborough, UK) antifade mounting medium. Sections were viewed at $\times 400$ using a microscope. The target DNA was denatured with $100 \mu \mathrm{L}$ of $70 \%$ formamide in $2 \times$ saline/ citrate buffer, $10 \mu \mathrm{L}$ of the probe applied and the slides incubated overnight in an Omnislide at $37^{\circ} \mathrm{C}$ (Hybaid, UK). Chromosome 17 and HER-2 copy number was evaluated using a direct dual-labelled technique, with the Pathvysion ${ }^{\mathrm{TM}}$ HER-2 DNA probe kit (Vysis, UK). This incorporated a Spectrum Green-labelled $\alpha$-satellite probe for chromosome 17 and a Spectrum Orangelabelled HER2 probe. Again, serial sections stained with haematoxylin and eosin were first examined microscopically to locate tumour areas and benign renal tissue. FISH-stained sections were then scanned at $\times 400$ to locate these regions. Three areas were identified and 20 nuclei assessed per area by two independent observers with $\times 40$ or $\times 100$ objectives. Signals per nucleus for chromosome 17 (green) and HER2 (orange) were counted and the results recorded manually; in all, 60 nuclei were assessed. Gene amplification was defined as a HER $2 /$ chromosome 17 ratio of $>2$. Based on values from controls tissues in our laboratory, the normal values for chromosome 17 were 1.35-1.85 (1.61 $\pm 3 \mathrm{sD})$ and for HER2 were 1.51-1.99 (1.75 $\pm 3 \mathrm{sD})$. Values of $>3$ SD over the mean were defined as polysomic (for chromosome 17) or showing increased HER2 copy number.

\section{Results}

Twenty-seven tumours were assessed from 19 men and eight women; 24 tumours were of the clear cell type, two were papillary and one was of a spindle-cell variant. The clinical details of the 27 patients are summarized in Table 1, based on the TNM classification and more generally by the Robson classification (Table 2).

Table 1 Summary of the clinical details, FISH and IHC results of the 27 patients with RCC

\begin{tabular}{|c|c|c|c|c|c|}
\hline \multirow[b]{2}{*}{ Case/Sex } & \multirow[b]{2}{*}{ Grade } & \multirow[b]{2}{*}{ TNM } & \multicolumn{2}{|c|}{ Copy number } & \multirow[b]{2}{*}{ IHC } \\
\hline & & & Chrom 17 & HER 2 & \\
\hline $1 / \mathrm{M}$ & 2 & T3NOMO & 1.51 & 1.68 & 0 \\
\hline $2 / \mathrm{F}$ & 2 & T2NOMO & 1.78 & 1.71 & 0 \\
\hline $3 / M^{*}$ & 4 & T3N2MO & 1.59 & 1.55 & 0 \\
\hline $4 / \mathrm{M}$ & 2 & T1NOMO & 1.85 & 1.69 & 0 \\
\hline $5 / \mathrm{M}^{*}$ & 3 & T3NOMO & 2.66 & 2.88 & 0 \\
\hline 6/F & 3 & T1NOM0 & 1.73 & 1.69 & 0 \\
\hline $7 / \mathrm{F}$ & 3 & T2NOMO & 2.5 & 2.88 & 0 \\
\hline $8 / \mathrm{F}$ & 4 & T1NOMO & 1.2 & 1.21 & 0 \\
\hline $9 / \mathrm{F}$ & 3 & T3NOMO & 1.73 & 1.74 & 2 \\
\hline 10/M & 2 & T3NOMO & 1.87 & 1.79 & 0 \\
\hline $11 / \mathrm{M}$ & 2 & T2NOMO & 1.19 & 1.18 & 0 \\
\hline $12 / \mathrm{M}$ & 3 & T1NOMO & 2.8 & 3.02 & 0 \\
\hline $13 / \mathrm{F}$ & 1 & T3NOMO & 1.71 & 1.63 & 0 \\
\hline $14 / \mathrm{M}$ & 3 & T3NXMO & 2.41 & 2.48 & 0 \\
\hline $15 / \mathrm{M}$ & 3 & T3N1M0 & 1.9 & 1.78 & 0 \\
\hline $16 / \mathrm{M}$ & 3 & T1NOMO & 1.75 & 1.78 & 0 \\
\hline $17 / \mathrm{M}$ & 3 & T2NXMO & 1.58 & 1.69 & 0 \\
\hline $18 / \mathrm{M} \dagger$ & 4 & T4NOMO & 2.03 & 1.65 & 0 \\
\hline 19/M & 3 & T2NOMO & 1.7 & 1.65 & 0 \\
\hline $20 / \mathrm{M}$ & 4 & T3NOMO & 2.16 & 2.2 & 0 \\
\hline $21 / \mathrm{M}$ & 2 & T2NOMO & 2.53 & 2.92 & 2 \\
\hline $22 / \mathrm{M}$ & 3 & T1NOMO & 1.74 & 1.87 & 2 \\
\hline $23 / \mathrm{M}$ & 2 & T1NXM0 & 1.73 & 1.84 & 0 \\
\hline $24 / M$ & 2 & T3NOMO & 2.32 & 2.37 & 0 \\
\hline $25 / \mathrm{M}$ & 3 & T3NOMO & 1.88 & 1.85 & 0 \\
\hline $26 / \mathrm{F}$ & 3 & T2NXMO & 1.83 & 1.71 & 1 \\
\hline $27 / \mathrm{F}$ & 3 & T2NXMO & 1.75 & 1.78 & 0 \\
\hline
\end{tabular}

*Represents the two papillary tumours and the spindle cell carcinoma. 
Table 2 The distribution of stage and tumour type in the tumours in the study, and the distribution of the RCCs with polysomy 17 and increased HER-2 copy number; both these genetic events were more frequent in more advanced stages

\begin{tabular}{lllllr}
\hline & \multicolumn{2}{l}{ Stage } & & & \\
\cline { 2 - 6 } $\begin{array}{l}\text { Tumour type } \\
\text { or result }\end{array}$ & $I$ & II & III & IV & N \\
\hline Clear cell & 6 & 6 & 7 & 5 & 24 \\
Papillary & 0 & 0 & 1 & 1 & 2 \\
Spindle cell variant & 0 & 0 & 0 & 1 & 1 \\
Total & 6 & 6 & 8 & 7 & 27 \\
Result: & 0 & 3 & 4 & 4 & \\
$\begin{array}{l}\text { Polysomy 17 } \\
\text { Increased HER2 }\end{array} \quad 0$ & 2 & 2 & 3 & \\
$\quad$ copy number & & & & & \\
IHC $(2+$ or 3+) & 2 & 1 & 0 & 0 & \\
\hline
\end{tabular}

All FISH hybridizations were successful; there was no gene amplification in any of the tumours or the benign renal tissue. The median (range) HER 2/chromosome 17 number was $0.99(0.8-1.17)$ for the tumours and $0.99(0.93-1.15)$ for benign tissue. The median chromosome 17 copy number for the tumours was $1.78(1.19-2.8)$ and 11 (41\%) were polysomic for chromosome 17. The median chromosome 17 copy number for benign renal tissue was 1.59 (1.5-1.79) and hence none was polysomic for chromosome 17 . The median HER2 copy number for the tumours was $1.76(1.18-3.02)$ and hence seven (26\%) had increased HER 2 copy number (all seven were also polysomic for chromosome 17). The median HER 2 copy number for benign renal tissue was $1.68(1.4-1.8)$ and hence none had increased HER2 copy number.

All the IHC was completed successfully; three tumours (11\%) over-expressed the HER2 protein $(2+)$; all other tumours were negative. Six of the seven benign renal tissues over-expressed the HER 2 protein $(3+)$; all these positive samples had a particular distribution of positively staining cells, confined to the distal nephron (Fig. 1a,b).

\section{Discussion}

Patients with metastatic RCC have a 5-year survival of only $10 \%$ and RCC is resistant to conventional chemotherapeutic agents [1,2]. The study of the molecular genetics of RCC may help to develop new therapeutic agents. Alterations of genes that function as regulators of cell growth and differentiation are considered to be crucial in the progression of human cancers [29]. Numerous genetic aberrations have been documented in RCC and many are associated with a poor clinical outcome [30]. For example, the EGFR (on chromosome 7) is over-expressed in $80 \%$ and there is
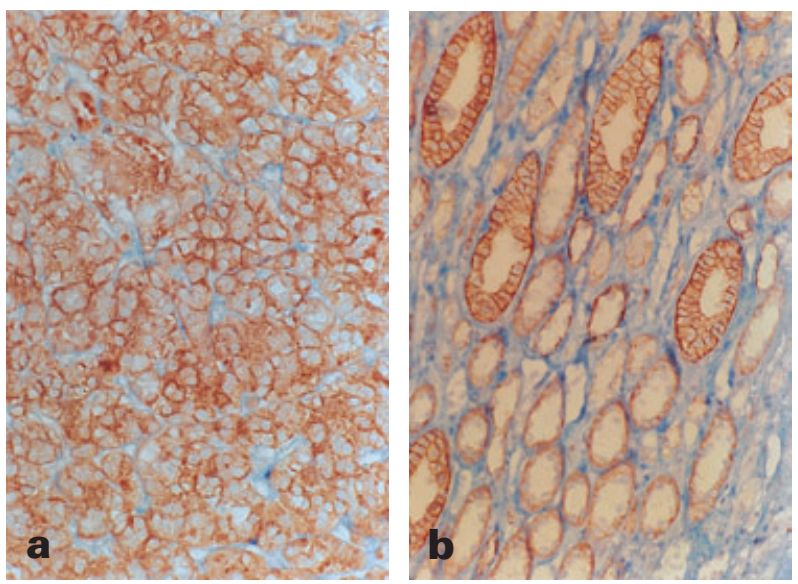

Fig. 1. Positively staining: a, RCC tissue, scored as a ' $2+$ ' and b, benign renal tissue; note the particular distribution of positively staining cells confined to the distal nephron in the latter. Both $\times 160$.

polysomy of chromosome 7 in $75 \%$ of RCCs, predicting a poor prognosis [31,32]. Polysomy 7 is linked to polysomy 17 in RCC $[4,5]$ and the HER2 oncogene is on chromosome 17. Over-expression/gene amplification of HER 2 has been reported for many human tumours and represents a poor prognostic factor in several [9,11-13]. HER2 gene amplification and protein overexpression are thought to be important in oncogenic transformation, tumorigenesis and metastasis [33]. For example, in breast cancer, patients whose tumours have gene amplification/protein over-expression $(15-30 \%$ of all patients) have a poorer prognosis. These patients respond to clinical treatment with the mAb Herceptin, which is targeted against the HER 2 cell surface receptor $[15,16]$. Herceptin has cytostatic growth inhibitory effects against breast cancer cells, and induces antibodydependent cellular cytotoxicity against human tumour cell lines, contributing to its antitumour activity [33].

There is a wide variation in the reported results for HER2 assessment in RCC, partly because of the differing laboratory techniques applied in the various studies. Rotter et al. [18] used slot-blot analysis and found no gene amplification in any of 24 tumours. Similarly Weidner et al. [19] (six tumours), Freeman et al. [20] (13 tumours) and Stuum et al. [21] (34 tumours) showed no gene amplification by Southern blot analysis in RCCs. Classical techniques for detecting gene amplification, like Southern blotting, need a large quantity of DNA and all have the problem of varying tumour content within a given specimen, which renders the results unreliable if the percentage of tumours cells is low in a sample [10]. More recently Zhang et al. [17] (70 tumours) used differential PCR and reported that $17 \%$ of tumours showed gene amplification for HER 2 in addition 
to a significant association with tumour stage. The conclusion was that HER2 abnormalities may be involved in the pathogenesis of RCC. Differential PCR must be rigorously controlled if it is to be used successfully to quantify mRNA or gene copy number [34]. Furthermore, the use of tissue homogenates, as used for southern analyses (see above), may further compromise the sensitivity of this technique. FISH is the preferred technique for visualizing HER2 in breast cancer diagnostics, because it assesses DNA in individual cells using a specific fluorescently labelled probe. Hence there is no need to microdissect tumour cells or to isolate nucleic acids before labelling, as with Southern blotting, and indeed FISH has been shown to be superior to other techniques in detecting HER 2 amplification on formalinfixed, paraffin-embedded material [10]. Comparing the results of studies estimating protein over-expression of HER2 is difficult because all have used different antibodies and scoring criteria. However, Stuum et al. [21] and Zhang et al. [17] reported that $64 \%$ and $40 \%$ of RCCs over-expressed the HER 2 protein using IHC, and that HER2 was important in the progression of RCC. In contrast, Rotter et al. [18] reported that HER2 protein over-expression was uncommon in RCC and that HER2 was not important in the progression of RCC. Consistent with this conclusion, others $[19,20]$ reported that mRNA levels were lower in RCCs than in normal tissue. Hence the exact role of HER 2 in the pathogenesis of RCC remains unclear.

In the present study of 27 RCCs and seven benign renal tissues examined for HER2 abnormalities using FISH and IHC, there was no gene amplification in any of the tissues. However, polysomy 17 occurred in $41 \%$ and increased HER 2 copy number in $26 \%$ of the tumours. Furthermore, polysomy 17 and increased HER2 copy number were more frequent in stage III and stage IV cancers (Table 2). Both polysomy 17 and increased HER2 copy number were absent in the benign renal tissue.

Protein was over-expressed in $11 \%$ of the tumours at $2+$ and in six of seven of the benign renal tissues at $3+$. Hence protein was strongly over-expressed $(3+)$ only in the benign renal tissue, confined to the distal parts of the nephron. There was no staining in the proximal tubules, which are the cells thought to give rise to RCC. This is consistent with results reported previously [19,20,35], suggesting that under-expression of HER 2 mRNA is characteristic of RCCs. Consistent with this, Rotter et al. [18] suggested that reduced HER2 protein and gene expression were inversely related to tumour differentiation, with less well differentiated tumour cells having lower HER2 expression. Current evidence suggests that in breast cancer only patients with tumours that are $3+$ on IHC or $2+$ with gene amplification, as shown by FISH, respond to Herceptin immunotherapy [36], implying that the advanced RCCs in the current study may be unresponsive to Herceptin.

The present results suggest that gene amplification and strong protein over-expression of HER2 is absent in RCC. This casts doubt on the suitability of Herceptin immunotherapy in the management of RCC.

\section{Acknowledgements}

The authors thank Professor T.G. Cooke for his support. This research was funded by The British Urology Foundation (BUF/Pfizer Scholarship 2000/2001) and The Royal College of Surgeons of Edinburgh.

\section{References}

1 Selli C, Hinshaw WM, Woodard BH, Paulson DF. Stratification of risk factors in renal cell carcinoma. Cancer 1983; 52: 899-903

2 Yagoda A, Abi-Rached B, Petrylak D. Chemotherapy for advanced renal-cell carcinoma: 1983-93. Semin Oncol 1995; 22: 42-60

3 Negrier S, Escudier B, Lasset C et al. Recombinant human interleukin-2, recombinant human interferon alfa-2a, or both in metastatic renal cell carcinoma. New Engl J Med 1998; 338: 1272-8

4 Corless CL, Aburatini H, Fletcher JA, Houseman DE, Ami MB, Weinberg DS. Papillary renal cell carcinoma. Quantitation of chromosomes 7 and 17 by FISH, analysis of chromosome 3p for LOH, and DNA ploidy. Diag Mol Pathol 1996; 5: 53-64

5 Brown JA, Borell TJ, Qian J, Bostwick DG, Jenkins RB. Simultaneous chromosome 7 and 17 gain and sex chromosome loss provide evidence that metanephric adenoma is related to papillary renal cell carcinoma. J Urol 1997; 158: 370-4

6 Schechter AL, Hung MC, Vaidyanathan L et al. The neu gene. An erbB-homologous gene distinct from and unlinked to the gene encoding the EGF receptor. Science 1985; 229: 976-8

7 Bargmann CI, Hung MC, Weinberg RA. The neu oncogene encodes An epidermal growth factor receptor-related protein. Nature 1986; 319: 226-30

8 Akiyama T, Sudo C, Ogawara H, Toyoshima K, Yamamoto T. The product of the human c-erbB-2 gene: a 185-kilodalton glycoprotein with tyrosine kinase activity. Science 1986; 232: 1644-6

9 Slamon DJ, Godolphin W, Jones LA et al. Studies of the HER-2/neu proto-oncogene in human breast and ovarian cancer. Science 1989; 244: 707-12

10 Pauletti G, Godolphin W, Press MF, Slamon DJ. Detection and quantitation of HER-2/neu gene amplification in human breast cancer archival material using fluorescence in situ hybridization. Oncogene 1996; 13: $63-72$ 
11 Slamon DJ, Clark GM, Wong SG, Levin WJ, Ullrich A, McGuire WL. Human breast cancer. Correlation of relapse and survival with amplification of the HER-2/neu oncogene. Science 1987; 235: 177-82

12 Schneider PM, Hung MC, Chiocca SM et al. Differential expression of the c-erbB-2 gene in human small cell and non-small cell lung cancer. Cancer Res 1989; 49: 4968-71

13 Press MF, Pike MC, Hung G et al. Amplification and overexpression of HER-2/neu in carcinomas of the salivary gland: correlation with poor prognosis. Cancer Res 1994; 54: 5675-82

14 Revillion F, Bonneterre J, Peyrat JP. ERBB2 oncogene in human breast cancer and its clinical significance. Eur J Can 1998; 34: 791-808

15 Cobleigh MA, Vogel CL, Tripathy D et al. Multinational study of the efficacy and safety of humanized antiHER2 monoclonal antibody in women who have HER2-overexpressing metastatic breast cancer that has progressed after chemotherapy for metastatic disease. J Clin Oncol 1999; 17: 2639-48

16 Baselga J, Tripathy D, Mendelsohn J et al. Phase II study of weekly intravenous recombinant humanized antip185HER2 monoclonal antibody in patients with HER 2/neu-overexpressing metastatic breast cancer. J Clin Oncol 1996; 14: 737-44

17 Zhang XH, Takenaka I, Sato C, Sakamoto H. p53 and HER-2 alterations in renal cell carcinoma. Urology 1997; 50: 636-42

18 Rotter M, Block T, Busch R, Thanner S, Hofler H. Expression of HER-2/neu in renal-cell carcinoma. Correlation with histologic subtypes and differentiation. Int J Cancer 1992; 52: 213-7

19 Weidner U, Peter S, Strohmeyer T, Hussnatter R, Ackermann R, Sies H. Inverse relationship of epidermal growth factor receptor and HER2/neu gene expression in human renal cell carcinoma. Cancer Res 1990; 50: 4504-9

20 Freeman MR, Washecka R, Chung LW. Aberrant expression of epidermal growth factor receptor and HER-2 (erbB-2) messenger RNAs in human renal cancers. Cancer Res 1989; 49: 6221-5

21 Stumm G, Eberwein S, Rostock-Wolf S et al. Concomitant overexpression of the EGFR and erbB-2 genes in renal cell carcinoma (RCC) is correlated with dedifferentiation and metastasis. Int J Cancer 1996; 69: 17-22

22 Ellis IO, Dowsett M, Bartlett J et al. Recommendations for HER-2 testing in the UK. J Clin Pathol 2000; 53: 890-2

23 Hermanek P, Hutter RVP, Sobin LH, Wagner G, Wittekind Ch. TNM Atlas. 4th edn. International Union against Cancer, 1997, 296-302

24 Robson CJ, Churchill BM, Anderson W. The results of radical nephrectomy for renal cell carcinoma. J Urol 1969; 101: 297-301

25 Fuhrman SA, Lasky LC, Limas C. Prognostic significance of morphologic parameters in renal cell carcinoma. Am J Surg Pathol 1982; 6: 655-63
26 Van de Vijver MJ. Assessment of the need and appropriate method for testing for the human epidermal growth factor receptor-2 (HER2). Eur J Can 2001; 37: S11-7

27 Bartlett JMS, Watters AD, Ballantyne SA, Going JJ, Grigor KM, Cooke TG. Is chromosome 9 loss a marker of disease recurrence in transitional cell carcinoma of the urinary bladder? Br J Cancer 1998; 77: 2193-8

28 Watters AD, Ballantyne SA, Going JJ, Grigor KM, Bartlett JMS. Aneusomy of chromosomes 7 and 17 predicts the recurrence of transitional cell carcinoma of the urinary bladder. BJU Int 2000; 85: 42-7

29 Strohmeyer GT, Slamon DJ. Proto-onocogenes and tumour suppressor genes in human urological malignancies. J Urol 1994; 151: 1479-97

30 Moch H, Presti JC, Sauter G et al. Genetic aberrations detected by comparative genomic hybridisation are associated with clinical outcome in renal cell carcinoma. Cancer Res 1996; 56: 27-30

31 Moch H, Sauter G, Bucholz N, Waldman FM, Mihatsch MJ. Epidermal growth factor receptor expression is associated with rapid tumour cell proliferation in renal cell carcinoma. Human Pathol 1997; 28: 1255-9

32 Moch H, Sauter G, Gasser TC et al. EGF-r gene copy number changes in renal cell carcinoma detected by FISH. J Pathol 1998; 184: 424-9

33 Baselga J. Clinical trials of Herceptin (trastuzumab). Eur J Can 2001; 37: S18-24

34 Bartlett JMS, Hulme MJ, Miller WR. Analysis of Camp RI alpha mRNA expression in breast cancer. Evaluation of quantitative PCR for routine use. Br J Cancer 1996; 73: $1538-44$

35 Yao M, Shuin T, Misaki H, Kubotoa Y. Enhanced expression of c-myc and epidermal growth factor receptor genes in primary human renal cell cancer. Cancer Res 1988; 48: 6753-7

36 Piccart M. Closing remarks and treatment guidelines. Eur J Can 2001; 37: 30-3

\section{Authors}

Z. Latif, ARCS(Ed), Research Fellow.

A.D. Watters, MSc, Research Assistant.

J.M.S. Bartlett, PhD, Senior Lecturer in Surgery.

M.A. Underwood, MD, FRCS(Urol), Consultant Urologist.

M. Aitchison, MD, FRCS(Urol), Consultant Urologist.

Correspondence: Z. Latif, Department of Surgery, Queen Elizabeth Building, Glasgow Royal Infirmary, Glasgow, G31 2ER, UK.

e-mail: zaklatif@hotmail.com

Abbreviations: FISH, fluorescent in-situ hybridization; IHC, immunohistochemistry. 